\title{
Separation and identification of some fatty acids and phenolic compounds from Portulaca oleracea L. and study their biological effect on two types of pathogenic bacteria
}

\author{
Fatimah Sultan ${ }^{1}$, Abd Al-Bar Al-Farha ${ }^{2 *}$, Ibtisam Shaaban ${ }^{2}$ \\ ${ }^{1}$ Department of Plant Production, Technical Agricultural College, Northern Technical University, Mosul, Iraq ${ }^{2}$ \\ ${ }^{2}$ Department of Animal Production, Technical Agricultural College, Northern Technical University, Mosul, Iraq
}

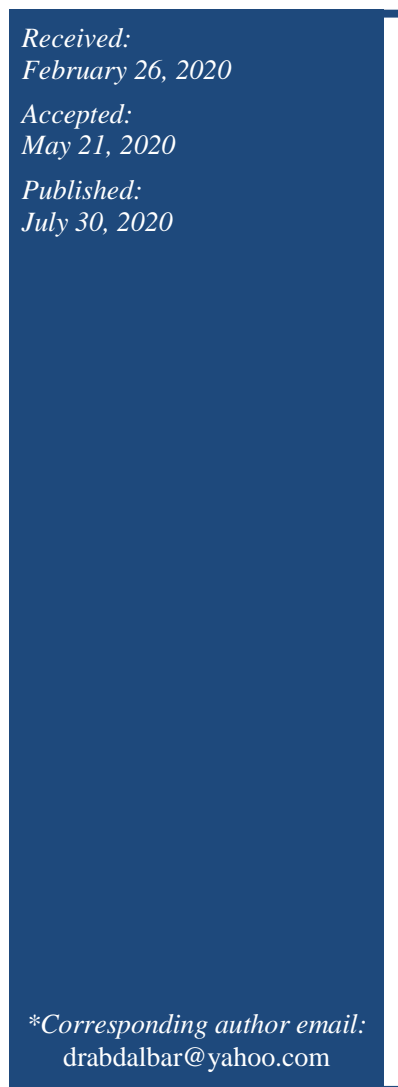

\begin{abstract}
This study aims to identify the chemical composition of purslane and examine its antimicrobial activities against two types of pathogenic bacteria: Pseudomonas savastanoi, and Staphylococcus aureus. Ether petroleum extract and ethanol extract were extracted using a Soxhlet extractor. Saponification was undertaken to separate the fatty acids from the crude ether petroleum extract. Then, high-performance liquid chromatography (HPLC) was used to detect these fatty acids. Acid analysis was carried out to extract the free phenols from the ethanol using gas liquid chromatography (GLC). The results showed that purslane leaves are rich in fatty acids including palmitic, oleic, linoleic, linolenic, and stearic acids. Additionally, using HPLC, five phenols were detected in the ethanol extract of the purslane leaves including quercetin, kaempferol, gallic acid, catechin and apigenin. Using the disc diffusion technique, both active extracted compounds were found to exhibit various inhibitory effects against the studied bacteria. However, the fatty acids showed a greater inhibitory effect than the phenols on both pathogens.
\end{abstract}

Keywords: Bioactive compounds, HPLC, Fatty acids, Phenolic compounds, Purslane

\section{How to cite this:}

Sultan F, Al-Farha AA and Shaaban I, 2020. Separation and identification of some fatty acids and phenolic compounds from Portulaca oleracea L. and study their biological effect on two types of pathogenic bacteria. Asian J. Agric. Biol. 8(3): 281-290. DOI: https://doi.org/10.35495/ajab.2020.02.119

This is an Open Access article distributed under the terms of the Creative Commons Attribution 3.0 License. (https://creativecommons.org/licenses/by/3.0), which permits unrestricted use, distribution, and reproduction in any medium, provided the original work is properly cited.

\section{Introduction}

Medical herbs and plants contain essential or active ingredients; these are chemical compounds that are generated as secondary products to the plants' metabolic processes. These compounds are useful for protection against other organisms and for maintaining life. Research has shown that many medical plant extracts have antimicrobial activities including clove, garlic, cinnamon, sage, marigold, flaxseed, thyme, and purslane. Several of the relevant studies have highlighted the antimicrobial effect of the bioactive compounds that have been extracted as groups such as fatty acids, phenolic compounds, and alkaloid compounds. Purification and identification of these compounds has attracted the attention of researchers. However, little is yet known about the purification of these compounds (Dalirsani et al., 2011). 
Portulaca oleracea, also known as common purslane, is a herbal, annual medicinal plant belonging to the Portulacaceae family and has a height of $30 \mathrm{~cm}$. $P$. oleracea has been widely described as an antioxidant due to its fatty acid constituents and its other bioactive compounds, particularly omega-3, linolenic acid, $\alpha$ linolenic acid, lotannins, ascorbic acid, and oxalic acid (Petropoulos et al., 2016).

Other phenolic compounds in purslane could contribute to its antioxidant activities (Karoune et al., 2017). Additional pharmaceutical effects of purslane, such as its anti-carcinogenic, anti-diabetic, and anticardiovascular disease effects, have been reported elsewhere (Al-Sheddi et al., 2015; Dehghan et al., 2016; Ramadan et al., 2017). Furthermore, purslane is rich in essential minerals such as calcium, phosphorus, and potassium (Petropoulos et al., 2019). It has been reported that purslane has antimicrobial activities against both gram-positive and gram-negative bacteria (Asad, 2018); antifungal activities, particularly against Trichophyton; antiviral activities (Dong et al., 2010); and significant analgesic and anti-inflammatory properties (Nudrat et al., 2018). This study aimed to separate and identify the many fatty acids and some of the phenolic compounds from Portulaca oleracea and study their biological effects on two types of pathogenic bacteria: Pseudomonas savastanoi, a plant pathogenic gram-negative bacterium, and Staphylococcus aureus, a gram-positive bacterium that generally affects animals.

\section{Material and Methods}

The methods of the current study include two aspects: phytochemistry and antimicrobial susceptibility of the studied bacteria.

\section{Phytochemistry Aspect \\ Plant collection and classification}

Leaves of $P$. oleracea were collected from the gardens of different houses in Mosul, Iraq. In accordance with the study by Townsend et al. (1980), classification was carried out at the Medical Plant Development Project, Ministry of Agriculture, Mosul Dam, Nineveh, Iraq.

\section{Preparation of plant extracts}

The preparation was carried out using a continuous Soxhlet apparatus. Extracts were prepared, dependent on the separated active ingredients and the type of solvent. Petroleum ether $\left(40^{\circ} \mathrm{C}-60^{\circ} \mathrm{C}\right)$ and ethanol
95\% were used in the extraction process. The extraction was conducted at different temperatures, all of which were below $80^{\circ} \mathrm{C}$, according to the solvent degree. Then the procedure was continued in accordance with that described by Harborne (1998).

\section{Separation of fatty acids Saponification}

Saponification was carried out in an alkaloid environment (Vogel, 1972). To extract the saponified materials from the petroleum ether, $100 \mathrm{~mL}$ of $\mathrm{KOH}$ $(7.5 \mathrm{~m})$ was added to $10 \mathrm{~g}$ of the extract; the temperature was then increased to $100^{\circ} \mathrm{C}$ for 90 minutes. The mixture was then cooled to the ambient temperature and $100 \mathrm{~mL}$ of distill water was added to obtain the emulsion form. The solution was filtered and the non-saponified fat was removed by adding $2 * 25$ ether. Next, the water solution was acidified by adding $20 \% \mathrm{H}_{2} \mathrm{SO}_{4}$ until the $\mathrm{pH}=2$ and the solution became clear. After that, the fatty acids were extracted using ether in filtered funnels and were preserved in dark glass bottles in the refrigerator until they were used for esterification.

\section{Esterification}

Methyl solution was added to the separated fatty acids to decrease their polarity and to make them more evaporated when using the diagnostic GLC technology. The esterification process was carried out following the method described previously by Loury (1967).

\section{Separation of phenolic compounds via acid hydrolysis}

Acid hydrolysis was conducted by adding $25 \mathrm{~mL}$ of (1N) HCL to $5 \mathrm{~mL}$ of concentrated refluxed ethyl extract. The temperature was increased to $100^{\circ} \mathrm{C}$ for an hour. The solution was filtered in funnels; then, $2 * 15$ of ethyl acetate was added while shaking. The upper organic layer was separated and dried using nonaquatic magnesium sulfate. The aquatic layer was disregarded and the ethyl acetate was evaporated using a circulating evaporator under pressure. The phenols were then preserved in the refrigerator in dark glass bottles until identification using HPLC (Harborne, 1998).

\section{Identification of bioactive compounds Gas liquid chromatography}

Identification of the fatty acids was conducted based on the retention time $\left(\mathrm{R}_{\mathrm{t}}\right)$ of the extracted samples in comparison with the retention time of the standard compounds. The process was conducted at the 
Aquatic and Ecology Center, Ministry of Science and Technology, Baghdad, Iraq using GLC (Shimadzu14A, Japan) and a flame ionization detector.

\section{High performance liquid chromatography}

The phenolic compounds were detected using HPLC (LC-2010AT SHIMADZU) at the following values: reference wavelength: $360 \mathrm{~nm}$, flow rate: 1.0 $\mathrm{mL} /$ minute, mobile phase: $\left(\mathrm{CH}_{3} \mathrm{CN}\right.$ :D.W: Orthophoric acid 60:35:5), column: C18-ODS (25 $\mathrm{cm}^{*} 4.6 \mathrm{~mm}$ ), column temperature: $30^{\circ} \mathrm{C}$. The process was conducted at the Aquatic and Ecology Center, Ministry of Science and Technology, Baghdad, Iraq.

\section{Antimicrobial aspect \\ Bacterial isolates}

Three bacterial isolates of each type were obtained from the bacterial bank, Microorganisms Laboratory, College of Science, University of Mosul, Mosul, Iraq. The isolates related to plant pathogenic gram-positive bacterium Pseudomonas savastanoi and animal pathogenic gram-positive bacterium Staphylococcus aureus. Identification of the isolates was confirmed based on the conventional culture method and biochemical tests. Nutrient agar (oxoid) and nutrient broth (himedia) were used following the instruction of each company.

\section{Antibiotics}

Three antibiotics were used in this study to compare their effects with the extracted compounds: amoxicillin (AX) $25 \mu \mathrm{g} /$ disc, gentamicin (CN) 10 $\mu \mathrm{g} / \mathrm{disc}$, and ceftriaxone (CRO) $10 \mu \mathrm{g} / \mathrm{disc}$ (Biqan Alyse Selted, Turkey).

\section{Agar diffusion assay}

The agar disc diffusion test was carried out according to CLSI (2011). Three to five colonies were selected, then inoculated in the nutrient broth and incubated at $37^{\circ} \mathrm{C}$ for 24 hours. The broth was diluted tenfold and $0.1 \mathrm{~mL}$ of it was cultured on Moller Hinton agar, where it was spread uniformly on the surface using a sterile cotton swab. The dishes were incubated at $37^{\circ} \mathrm{C}$ for 30 minutes for impregnation. In the meantime, the tablets were saturated with the active ingredients that had been extracted from the leaves of the purslane plant. Whatman filter paper 1 with a diameter of $6 \mathrm{~mm}$ was used and $0.1 \mathrm{~cm}^{3}$ of the concentrated extracts $(200$, $100,50,25 \mathrm{mg} / \mathrm{cm}^{3)}$ and the active ingredients were added to a vial containing 10 sterile tablets (Miladinovic and Miladinovic, 2000). The saturated discs were stabilized at different concentrations using sterile forceps in the nutrient agar medium, at a rate of three repetitions. They were then incubated at $37^{\circ} \mathrm{C}$ for 14-16 hours. The diameter of the inhibition zone was determined using the lowest inhibitory concentration; then, the highest dilution of the plant extract that inhibited bacterial growth was identified (Forber et al., 2007). The results were compared with several of the selected antibiotics as a positive bacterial control, based on the public health laboratories that follow the World Health Organization (WHO) standards (CLSI, 2011).

\section{Statistical analysis}

The data were analyzed using statistical analysis software. The significant random differences between the averages were tested in accordance with the Duncan test at $\mathrm{p} \leq 0.01$ significance.

\section{Results and Discussion}

The current study aimed to separate and identify the fatty acids and phenolic compounds from Portulaca oleracea and study their biological effects on two types of pathogenic bacteria: Pseudomonas savastanoi and Staphylococcus aureus. GLC chromatograms showed the presence of five fatty acids, including oleic, linolenic, linoleic, palmitic, and stearic acids, and their concentrations are shown in Figure 1 and Table 1.

Table-1: Retention time (minute) and concentrations of the extracted fatty acids compared with the standard fatty acids measured by GLC.

\begin{tabular}{|c|c|c|}
\hline No. & Compounds & $\begin{array}{c}\text { Standard retention } \\
\text { time (min) }\end{array}$ \\
\hline 1 & Palmitic acid & 3.97 \\
\hline 2 & Oleic acid & 5.38 \\
\hline 3 & Linoleic acid & 5.88 \\
\hline 4 & Linolenic acid & 7.96 \\
\hline 5 & Stearic acid & 8.75 \\
\hline
\end{tabular}


Fatimah Sultan et al.
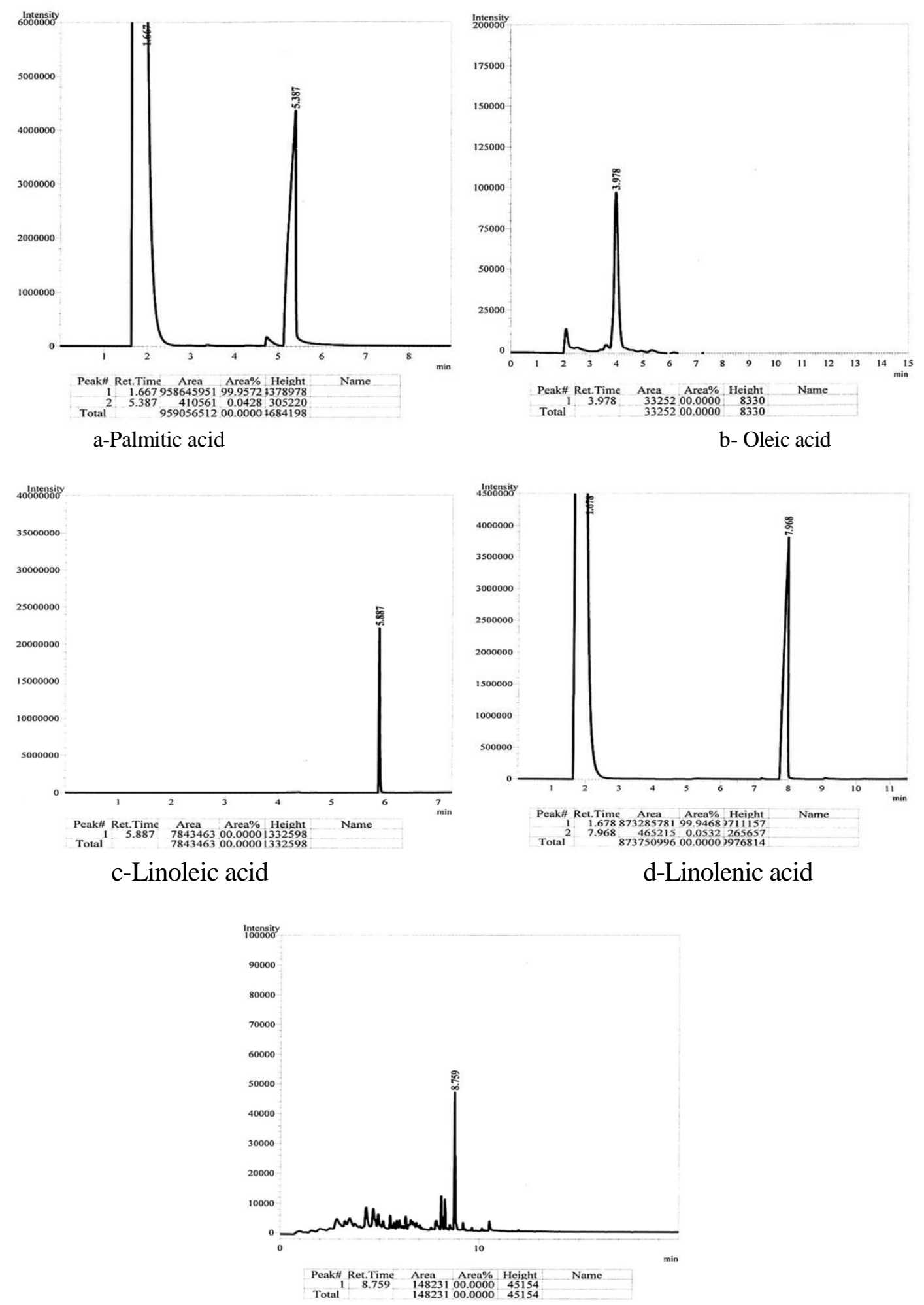

e-Stearic acid

Figure-1. GLC chromatograms of the standard fatty acid compounds. 
In addition, Table 2 and Figure 2 show the concentrations and retention times of the fatty acids extracted from the ether petroleum extract of the purslane leaves using GLC technology. Five fatty acids were identified after saponification; these were palmitic acid, 0.0058; linoleic acid, 0.0080; linolenic acid, 0.0330; stearic acid, 0.0084; and oleic acid 0.0231 . The retention time of the extracted fatty acids was compared with the $\mathrm{R}_{\mathrm{t}}$ of the standard compounds: linoleic, oleic, linolenic, palmitic, and stearic acids. It was shown that the linolenic acid had the highest concentration among all the extracted fatty acids, while the palmitic acid had the lowest concentration (Table 1). These results are in-line in keeping with the findings of Asadi Gharneh et al. (2012). Furthermore, a study by Karoune et al. (2017) showed similar findings, particularly for the presence of linolenic acid.

The essential omega acids were therefore present in the petroleum ether extraction of purslane after saponification. Omega-3 (linolenic acid), omega-6 (linoleic acid), and omega-9 (stearic and oleic acids), for example, are well known to have positive effects on public health: omega- 3 is an unsaturated fatty acid composed of Eicosapentaenoic (EPA) and Docosahexaenoic (DHA) acids and contains three double bonds, playing a significant role in lowering cholesterol levels. Other advantages of these acids include anti-Alzheimer activity, enhancing the activity of fetal brains, reducing arthritis, boosting mental concentration, reducing cardiovascular risks, and improving lung health.
Linolenic acid is used for building omega- 6 fatty acids; these are considered as essential in maintaining the normal function of body tissues. The WHO recommends using a normal ratio of these fatty acids at $15: 1$ to $5: 1$ of omega-6 to omega-3. Omega-9 is a fatty acid that is composed of stearic acid and oleic acid. Stearic acid is a saturated fatty acid and can be converted to oleic acid (Okuyama et al., 2007).

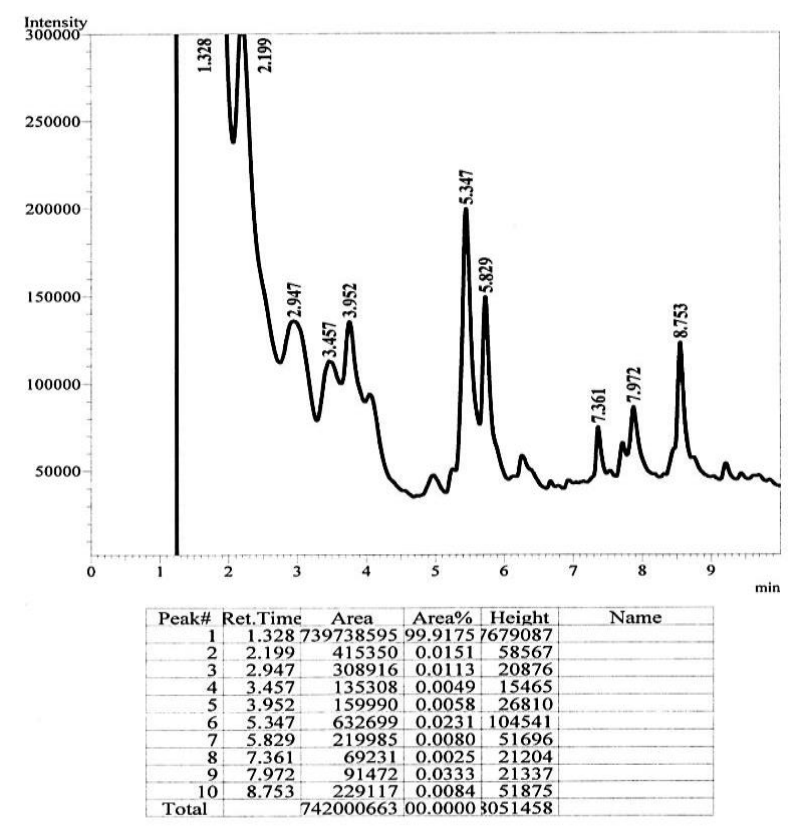

Figure-2: GLC chromatograms of the fatty acid compounds present in Portulaca oleracea $\mathbf{L}$.

Table-2: GLC analysis of the fatty acid compound extracts in Portulaca oleracea $\mathbf{L}$.

\begin{tabular}{|c|c|c|c|c|c|c|c|c|c|c|}
\hline Fatty acid & \multicolumn{2}{|c|}{ Palmitic } & \multicolumn{2}{|c|}{ Oleic } & \multicolumn{2}{|c|}{ Linoleic } & \multicolumn{2}{|c|}{ Linolenic } & \multicolumn{2}{|c|}{ Stearic } \\
\hline Standards $\mathrm{R}_{\mathrm{t}}(\mathrm{min})$ & \multicolumn{2}{|c|}{3.97} & \multicolumn{2}{|c|}{5.38} & \multicolumn{2}{|c|}{5.88} & \multicolumn{2}{|c|}{7.96} & \multicolumn{2}{|c|}{8.75} \\
\hline Samples & $\begin{array}{c}\text { Conc. } \\
(\%)\end{array}$ & $\begin{array}{c}\mathrm{R}_{\mathrm{t}} \\
(\mathrm{min})\end{array}$ & $\begin{array}{c}\text { Conc. } \\
(\%)\end{array}$ & $\begin{array}{c}\mathrm{R}_{\mathrm{t}} \\
(\mathrm{min})\end{array}$ & $\begin{array}{c}\text { Conc. } \\
(\%)\end{array}$ & $\begin{array}{c}\mathrm{R}_{\mathrm{t}} \\
(\mathrm{min})\end{array}$ & $\begin{array}{c}\text { Conc. } \\
(\%)\end{array}$ & $\begin{array}{c}\mathrm{R}_{\mathrm{t}} \\
(\mathrm{min})\end{array}$ & $\begin{array}{c}\text { Conc. } \\
(\%)\end{array}$ & $\begin{array}{c}\mathrm{R}_{\mathrm{t}} \\
(\mathrm{min})\end{array}$ \\
\hline $\begin{array}{l}\text { Fatty acid extract } \\
\text { from Portulaca }\end{array}$ & 0.0058 & 3.952 & 0.0231 & 5.347 & 0.0080 & 5.829 & 0.0330 & 7.972 & 0.0084 & 8.753 \\
\hline
\end{tabular}


Fatimah Sultan et al.

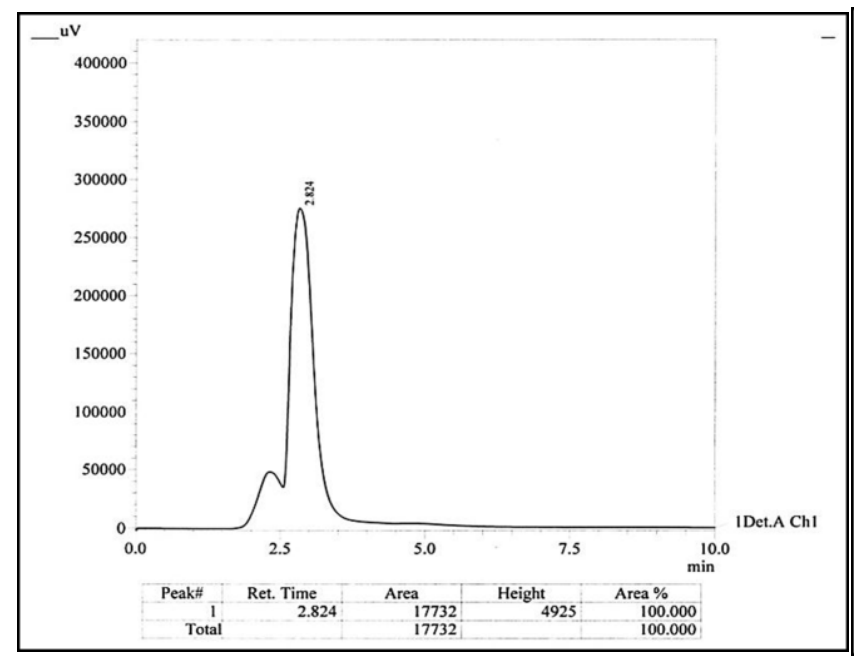

A-Quercetin

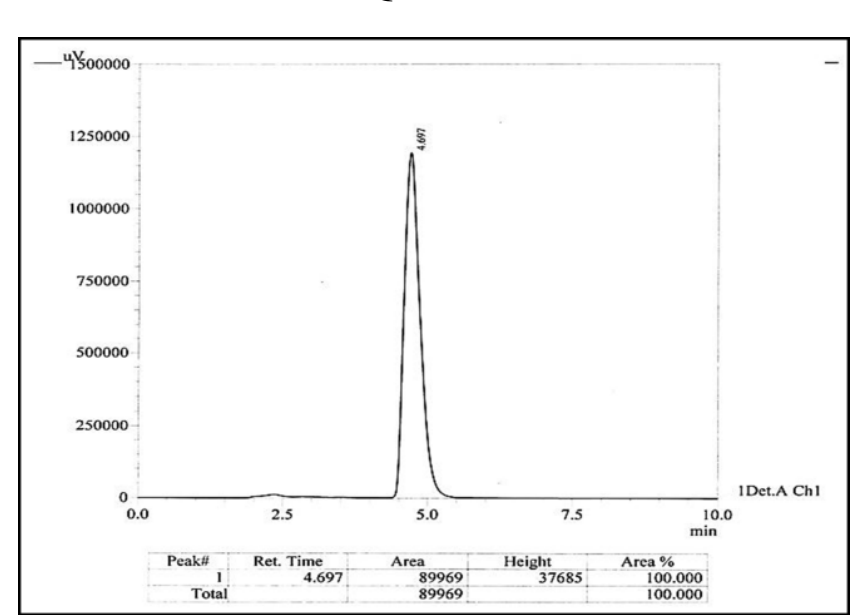

C-Gallic acid

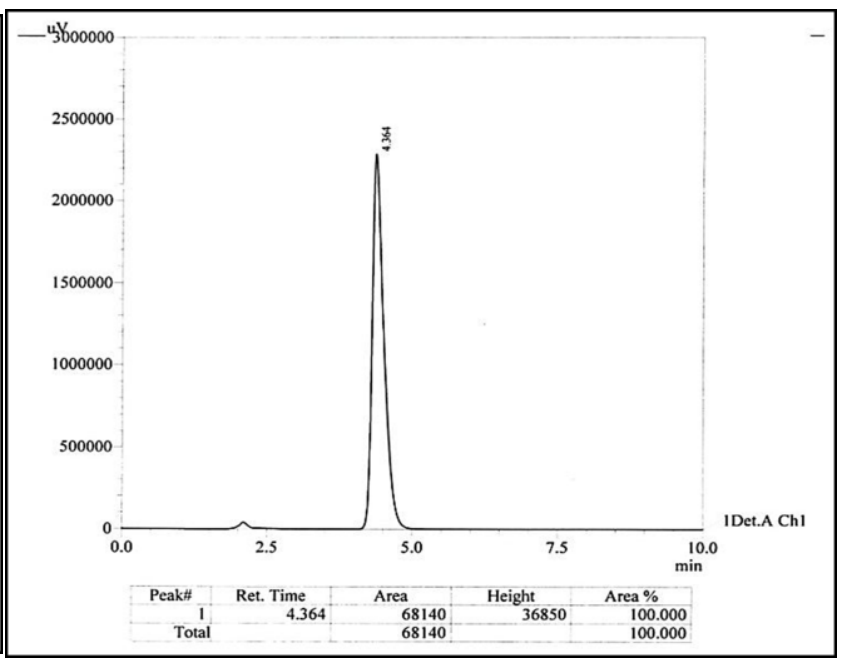

B-Kaempferol

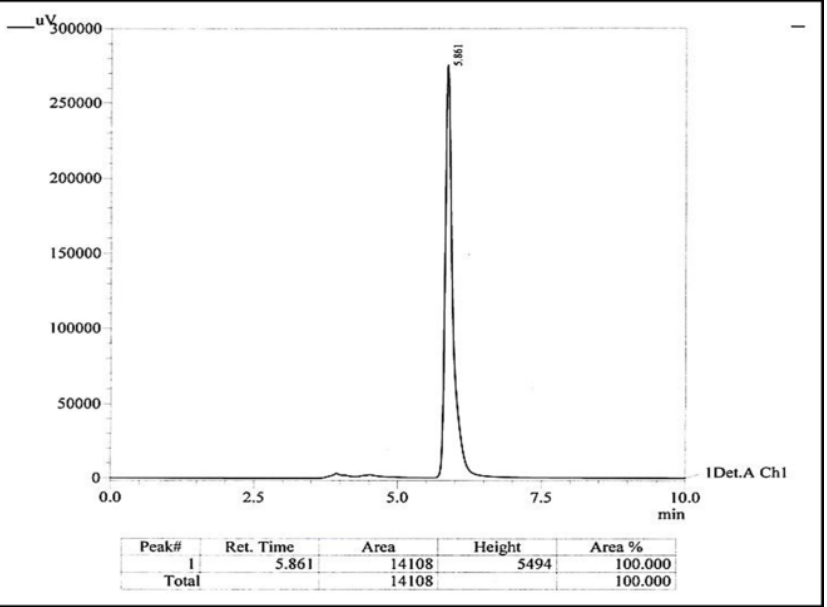

D-Catechin

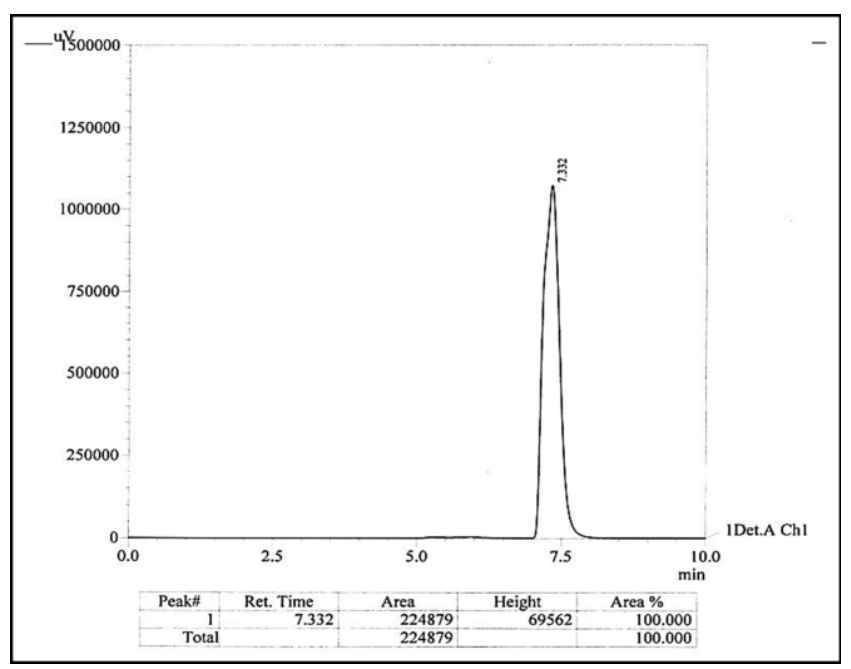

E-Apigenin

Figure-3: HPLC analysis of the standard phenolic compounds. 
The standard phenolic compounds and the phenolic ethanol extract were injected with $1 \mu \mathrm{L}$ in the HPLC after dissolving $0.1 \mathrm{~g}$ of the standard compound or the extract in $10 \mathrm{~mL}$ of ethanol. The separation and diagnosis resulted in a standard peak curve for each of the phenolic compounds, as well as their retention times. The ethanol extract also showed a difference in its content of phenolic compounds, which appeared in different concentrations, with different retention times and areas under the curve, which represented the concentrations of the separated compounds (Table 3 and Figures 3 and 4). The results of the current study were similar to those of Karoune et al. (2017) with regard to the phenolic contents of purslane, which are believed to affect the interactions of their active compounds with some medicinal drugs.

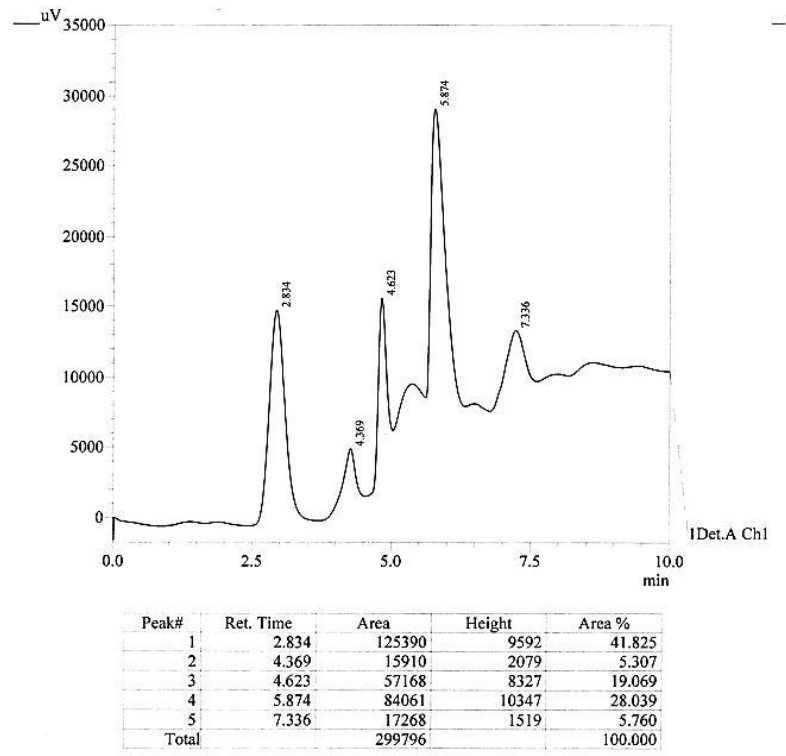

Figure-4: HPLC analysis of the phenolic compounds present in the Portulaca oleracea $L$. extract.
Three bacterial isolates of each type were collected from the Microbiology Bank of the Faculty of Science, University of Mosul. Table 4 shows the effects of the phenolic compounds and the fatty acids extracted from the leaves of the purslane plant on the studied bacteria compared with the standard antibiotics. The extracted fatty acids showed a highly significant inhibitory effect against both of the studied pathogens in comparison with amoxicillin and gentamicin. The sensitivity of Pseudomonas savastanoi to the fatty acids was weak compared to ceftriaxone. However, the fatty acids showed a high inhibitory effect against Staphylococcus aureus compared to ceftriaxone. The inhibitory effect of the fatty acid extracts may be attributable to the presence of palmitic, oleic, linolenic, linoleic, and stearic acids. These fatty acids can inhibit the intake of oxygen, leading to decreased ATP production and then cell death. They can also inhibit the protein and nucleic acid synthesis that is essential to cells and can inhibit plasma membrane synthesis.

The phenols separated from the ethanol extract of purslane leaves showed a high inhibitory effect against both studied bacteria compared to amoxicillin and gentamicin; they also exhibited good inhibition against Staphylococcus aureus compared to ceftriaxone, while the effect was low against Pseudomonas savastanoi compared to ceftriaxone. The effect is attributed to the separated phenolic compounds (quercetin, kaempferol, gallic acid, catechin, and apigenin). Phenols are very important bactericidal inhibitors: for example, gallic acid is known to be the most effective inhibitor against various tested pathogens (Tesaki et al., 1999).

Table-3: HPLC analysis of the phenolic compound extracts of Portulaca oleracea $\mathrm{L}$.

\begin{tabular}{|c|c|c|c|c|c|c|c|c|c|c|}
\hline $\begin{array}{l}\text { Phenolic } \\
\text { compounds }\end{array}$ & \multicolumn{2}{|c|}{ Quercetin } & \multicolumn{2}{|c|}{ Kaempferol } & \multicolumn{2}{|c|}{ Gallic acid } & \multicolumn{2}{|c|}{ Catechin } & \multicolumn{2}{|c|}{ Apigenin } \\
\hline Standards $\mathrm{R}_{\mathrm{t}}(\min )$ & \multicolumn{2}{|c|}{2.82} & \multicolumn{2}{|c|}{4.364} & \multicolumn{2}{|c|}{4.69} & \multicolumn{2}{|c|}{5.86} & \multicolumn{2}{|c|}{7.33} \\
\hline Samples & $\begin{array}{l}\text { Conc. } \\
(\mathrm{mg} / \mathrm{g})\end{array}$ & $\begin{array}{c}\mathrm{R}_{\mathrm{t}} \\
(\mathrm{min})\end{array}$ & $\begin{array}{l}\text { Conc. } \\
(\mathrm{mg} / \mathrm{g})\end{array}$ & $\begin{array}{c}\mathrm{R}_{\mathrm{t}} \\
(\mathrm{min})\end{array}$ & $\begin{array}{l}\text { Conc. } \\
(\mathrm{mg} / \mathrm{g})\end{array}$ & $\begin{array}{c}\mathrm{R}_{\mathrm{t}} \\
(\mathrm{min})\end{array}$ & $\begin{array}{l}\text { Conc. } \\
(\mathrm{mg} / \mathrm{g})\end{array}$ & $\begin{array}{c}\mathrm{R}_{\mathrm{t}} \\
(\mathrm{min})\end{array}$ & $\begin{array}{l}\text { Conc. } \\
(\mathrm{mg} / \mathrm{g})\end{array}$ & $\underset{(\min )}{\mathrm{R}_{\mathrm{t}}}$ \\
\hline $\begin{array}{l}\text { Phenolic } \\
\text { compounds extract } \\
\text { from Portulaca }\end{array}$ & 41.825 & 2.834 & 5.307 & 4.369 & 19.069 & 4.623 & 28.039 & 5.874 & 5.760 & 7.336 \\
\hline
\end{tabular}


Table-4. Antibacterial activity of the fatty acids and phenolic compounds of Portulaca oleracea $\mathrm{L}$. extract in some pathogenic bacteria (mn) compared with a standard antibiotic (con. 200 $\mathbf{m g} / \mathrm{cm}^{3}$ ).

\begin{tabular}{|l|c|c|}
\hline \multirow{2}{*}{\multicolumn{1}{c|}{ Type of treatment }} & \multicolumn{2}{|c|}{ Bacteria } \\
\cline { 2 - 3 } & $\begin{array}{c}\text { Staphylococcus } \\
\text { aureus }\end{array}$ & $\begin{array}{c}\text { Pseudomonas } \\
\text { savastanoi }\end{array}$ \\
\hline Fatty acids & 20 & 14 \\
\hline Phenolic compounds & 19 & 13 \\
\hline Amoxicillin $(\mathrm{AX}) 25 \mu \mathrm{g} / \mathrm{disc}$ & 12 & $\mathrm{~N}$ \\
\hline Gentamicin $(\mathrm{CN}) 10 \mu \mathrm{g} / \mathrm{disc}$ & 15 & 20 \\
\hline Ceftriaxone $(\mathrm{CRO}) 10 \mu \mathrm{g} / \mathrm{disc}$ & 18 & 15 \\
\hline
\end{tabular}

N: Inactive (Vandepitte, 2003).

Phenolic compounds also inhibit bacterial growth, by inhibiting the enzymes responsible for metabolic reactions, as a result of their non-specialized interaction with proteins, resulting in protein monsterization and subsequent bacterial death (Mason and Bruce, 1987; Williams and Lewis, 2011). Tables 5 and 6 and Figures 1 and 2 show the effect of the separated active compounds with different concentrations against the studied bacteria. The separated fatty acids showed a clear inhibitory effect against these bacteria. The highest inhibiting diameter of the fatty acid extract was $20.3 \mathrm{~mm}$ against Staphylococcus aureus and $14.3 \mathrm{~mm}$ against Pseudomonas savastanoi at a concentration of 200 $\mathrm{mg} / \mathrm{cm}^{3}$. The effect was directly proportional to the concentrations, with significant differences $(p \leq 0.01)$ between the rates of inhibition diameters of the different concentration groups as the fatty acid compounds were effective in all the concentrations of germs used in this study, as shown in Table 5 and Picture 1.

Table-5: Effect of fatty acids separated from purslane leaves on two bacteria used in different concentrations.

\begin{tabular}{|c|c|c|}
\hline $\begin{array}{c}\text { Concentrations } \\
\left(\mathbf{m g} / \mathbf{c m}^{\mathbf{3}}\right)\end{array}$ & $\begin{array}{c}\text { Staphylococcus } \\
\text { aureus }\end{array}$ & $\begin{array}{c}\text { Pseudomonas } \\
\text { savastanoi }\end{array}$ \\
\hline 200 & A 20.3 & A 14.3 \\
\hline 100 & A 18.6 & A 12.3 \\
\hline 50 & B 15 & B 10 \\
\hline 25 & C 13 & C 8.3 \\
\hline
\end{tabular}

- The diameter of the inhibition circuit according to the use of three isolates for each bacterium.

- Vertically different letters indicate the presence of significant differences at the level of moral difference $(\mathrm{p} \leq 0.01)$.
- The diameter of the damping circle measured in $\mathrm{mm}$. (-) Inactive.

The extracted phenols from purslane showed a lower inhibitory effect than fatty acids against the two microbes used in this study. The highest concentration that could inhibit Pseudomonas savastanoi was 200 $\mathrm{mg} / \mathrm{mL}$ with $13.6 \mathrm{~mm}$, and Staphylococcus aureus with $19.3 \mathrm{~mm}$. A positive correlation between the rest of the concentrations and the inhibition diameters was recorded. The results of the statistical analysis showed significant differences between the rate of inhibition diameter and the effect of each concentration, as shown in Table 6 and Picture 2.
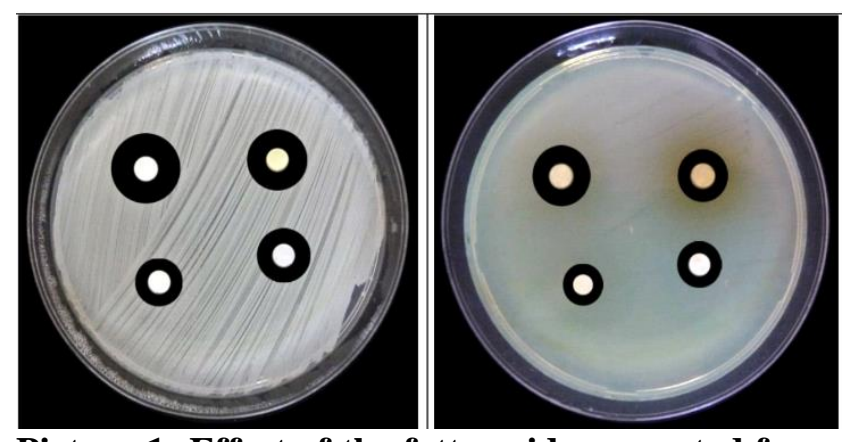

Picture 1: Effect of the fatty acids separated from the leaves of the purslane at different concentrations in germs (A) Staphylococcus aureus and (B) Pseudomonas savastanoi.

- The diameter of the inhibition circuit according to the use of three isolates for each bacterium.

- Vertically different letters indicate the presence of significant differences at the level of moral difference $(\mathrm{p} \leq 0.01)$.

- The diameter of the damping circle measured in mm.

$$
\text { (-) Inactive. }
$$
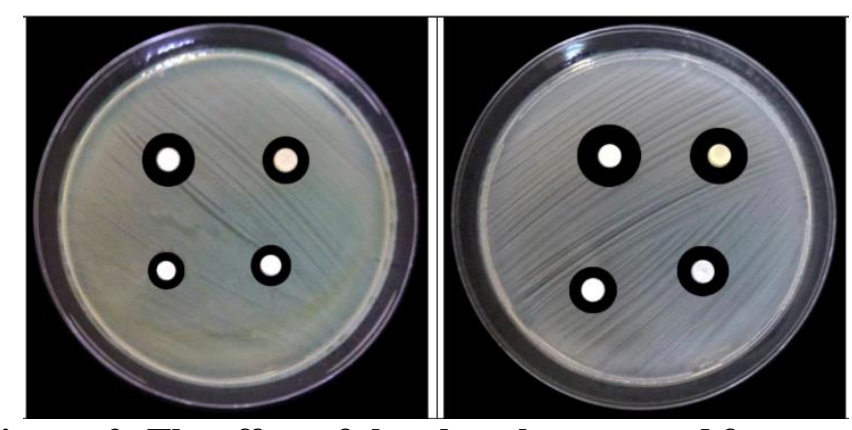

Picture 2: The effect of the phenols separated from the ethanol extract of purslane with different concentrations in germs (A) Staphylococcus aureus and (B) Pseudomonas savastanoi. 
Table-6. The effect of the phenols separated from purslane leaves on the two bacteria used in different concentrations.

\begin{tabular}{|c|c|c|}
\hline $\begin{array}{c}\text { Concentrations } \\
\left(\mathbf{m g} / \mathbf{c m}^{\mathbf{3}}\right)\end{array}$ & $\begin{array}{c}\text { Staphylococcus } \\
\text { aureus }\end{array}$ & $\begin{array}{c}\text { Pseudomonas } \\
\text { savastanoi }\end{array}$ \\
\hline 200 & A 19.3 & A 13.6 \\
\hline 100 & A 18 & A 12.6 \\
\hline 50 & B 15 & B 10.3 \\
\hline 25 & C 12 & C 8 \\
\hline
\end{tabular}

\section{Conclusion}

To summarize, purslane leaves are rich in fatty acids, including palmitic, oleic, linoleic, linolenic and stearic acids. In addition, in this study, five phenols were detected in the ethanol extract of purslane leaves using HPLC, including quercetin, kaempferol, gallic acid, catechin, and apigenin. Using the disc diffusion test, both active extracted compounds showed various inhibitory effects against the studied bacteria. However, the fatty acids showed a greater inhibitory effect than the phenols on both of the studied pathogens. The implications of this study may raise awareness of the dietary values of purslane. The results of this study may contribute to the reduction of antimicrobial usage in veterinary medicine and the animal care industry. Consequently, the challenges of antimicrobial residues and antimicrobial resistance could be avoided. Further research is needed to evaluate the antibacterial action of purslane against other bacteria.

Disclaimer: None.

Conflict of Interest: None.

Source of Funding: None.

\section{References}

Al-Sheddi E, Farshori N, Al-Oqail M, Musarrat J, AlKhedhairy A and Siddiqui M, 2015. Portulaca oleracea seed oil exerts cytotoxic effects on human liver cancer (HepG2) and human lung cancer (A-549) cell lines. Asian Pac. J. Cancer Prevent. 16(8): 3383-3387. doi: 10.7314/apjcp. 2015.16.8.3383.

Asad F, 2018. Efficacy of different solvent extracts from selected medicinal plants for the potential of antibacterial activity. Pure Appl. Biol. 7(2). doi: 10.19045/bspab.2018.700108
Asadi Gharneh H, and Reza Hassandokht M, 2012. Chemical composition of some Iranian purslane (Portulaca oleracea) as a leafy vegetable in south parts of Iran. Acta Horticulturae. 944: 41-44. doi: 10.17660/actahortic.2012.944.4.

CLSI (Clinical \& Laboratory Standards Institute), 2011. CLSI Guidelines. Mo2 and Mo7, 31(1): 6880. Retrieved on 7 February 2020 from https://clsi.org/

Dalirsani Z, Adibpour M, Aghazadeh M, Amirchaghmaghi M, Falaki F, Mozafari P and Hamzei F, 2011. In vitro comparison of inhibitory activity of 10 plant extracts against Candida albicans. Austr. J. Basic Appl. Sci. 5(5): 930-935.

Dehghan F, Soori R, Gholami K, Abolmaesoomi M, Yusof A and Muniandy S, 2016. Purslane (Portulaca oleracea) seed consumption and aerobic training improves biomarkers associated with atherosclerosis in women with type 2 diabetes (T2D). Sci. Reports. 6(1). doi: 10.1038/srep 37819.

Dong C, Hayashi K, Lee J and Hayashi T, 2010. Characterization of structures and antiviral effects of Polysaccharides from Portulaca oleracea L. Chem. Pharmaceut. Bull. 58(4): 507-510. doi: 10.1248/cpb.58.507.

Forber B, Sahm F and Weissfeld S, 2007. Diagnostic Microbiology $12^{\text {th }}$ ed., Mosby. pp. 288-302

Harborne J, 1998. Phytochemical Methods. Third ed., Springer, Dordrecht, Netherlands.

Karoune S, Kechebar M, Douffi H and Djellouli A, 2017. Phenolic compounds and their antioxidant activities in Portulaca oleracea L. related to solvent extraction. Int. J. Biosci. 11(1): 147-155. doi: 10.12692/ijb/11.1.147-155.

Loury M, 1967. A general method for rapid conversion of fats to methyl esters. Revue Francaise Des Corps Gras. 14: 383-389.

Mason T and Bruce PW, 1987. Inactivation of red beet $\beta$-glucan synthase by native and oxidized phenolic compounds. Phytochem. 26(8): 21972202. doi: 10.1016/s0031-9422(00)84683-x

Miladinovic D and Miladinovic L, 2000. Antimicrobial activity of essential oil of sage from Serbia. Physics Chem. Technol. 2: 97-100.

Nudrat F, Syed S, Ahmed M, Mehjabeen and Jahan A, 2018. A comparison of analgesic and antiInflammatory activities of Portulaca oleracea leaf and seeds. RADS J. Pharm. Pharmaceut. Sci. 6:194-199. 
Okuyama H, Yuko I, Yueji S, Tomohito H and William M, 2007. "Fatty acids effectively prevent coronary heart disease and other late-onset diseases: the excessive linoleic acid syndrome. World review of Nutritional dietetics 96 Prevention of coronary heart disease. Basel: Karger. 83-103.

Petropoulos S, Fernandes Â, Dias M, Vasilakoglou I, Petrotos K, Barros L and Ferreira I, 2019. Nutritional value, chemical composition and cytotoxic properties of common purslane (Portulaca oleracea L.) in relation to harvesting stage and plant part. Antioxidants. 8(8): 293. doi: 10.3390/antiox8080293.

Petropoulos S, Karkanis A, Martins N and Ferreira I, 2016. Phytochemical composition and bioactive compounds of common purslane (Portulaca oleracea L.) as affected by crop management practices. Trends Food Sci. Technol. 55: 1-10. doi: 10.1016/j.tifs.2016.06.010.

Ramadan B, Schaalan M and Tolba A, 2017. Hypoglycemic and pancreatic protective effects of Portulaca oleracea extract in alloxan induced diabetic rats. BMC Complement. Altern. Med. 17(1). doi: 10.1186/s12906-016-1530-16E.S.

Tesaki S, Tanabe S, Moriyama M, Fukushi E, Kawabata J and Watanabe M, 1999. Isolation and identification of an antibacterial compound from grape and its application to foods. J. Agric. Chem. Soc. Japan. 73(2): 125-128. doi: 10.1271/nogeikagaku1924.73.125

Townsend C, Guest E and Omar S, 1980. Flora of Iraq. Baghdad: Ministry of Agriculture \& Agrarian Reform, Republic of Iraq.

Vandepitte J, 2003. Basic laboratory procedures in clinical bacteriology. Geneva: World Health Organization.

Vogel A, 1972. A Text-Book of Practical Organic Chemistry Including Qualitative Organic Analysis. London: Longman.

Williams D and Lewis M, 2011. Pathogenesis and treatment of oral candidiasis. J. Oral Microbiol. 3(1): 5771 doi: 10.3402/jom.v3i0.5771.

\section{Contribution of Authors}

Sultan F: Conceived idea, data collection, data analysis, manuscript writing, manuscript final reading and approval

Al-Farha AA: Data interpretation, literature review, manuscript writing, manuscript final reading and approval

Shaaban I: Designed research methodology, data interpretation, manuscript final reading and approval 